\title{
Synthesis and Ceramization of Polymethylsilane Precursors Modified with Metal Chlorides
}

\author{
Masaki NARISAWA, Hiroaki TANNO, Masayuki IKEDA, Takashi ISEKI, Hiroshi MABUCHI, \\ Kiyohito OKAMURA, Kunio OKA, ${ }^{*}$ Takaaki DOHMARU** and Dong-Pyo KIM***
}

Department of Materials Science, Graduate School of Engineering, Osaka Prefecture University, 1-1, Gakuen-cho, Sakai-shi 599-8531

*Department of Applied Chemistry, Graduate School of Engineering, Osaka Prefecture University, 1-1, Gakuen-cho, Sakai-shi $599-8531$

${ }^{* *}$ Graduate School of Engineering, Osaka Prefecture University, 1-1, Gakuen-cho, Sakai-shi 599-8531

*** Department of Fine Chemical Engineering and Chemistry, Chungnam National University, 220 Kung-Dong, Yusung-gu, Daejon 305-764, Korea

\author{
金属塩化物で修飾したポリメチルシラン前駆体の合成とセラミゼーション

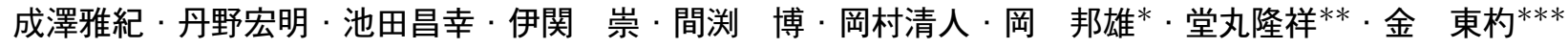 \\ 大阪府立大学工学研究科マテリアル工学科, 599-8531 大阪府界市学園町 1-1 \\ *大阪府立大学工学研究科応用化学科, 599-8531 大阪府堺市学園町 1-1 \\ **大阪府立大学工学研究科, 599-8531 大阪府堺市学園町 1-1 \\ ***忠南大学校精密化学工業科, 305-764 大田広域市儒城区弓洞 220
}

\begin{abstract}
Polymethylsilane (PMS) modified with titanium chloride $\left(\mathrm{TiCl}_{4}\right)$ or molybdenum chloride ( $\mathrm{MoCl}_{5}$ ) was pyrolyzed at various temperatures to enable a detailed investigation of stable phases formed during pyrolysis. The

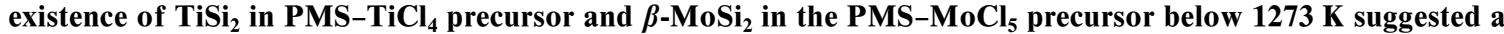
strong interaction between Si-H and the metal chlorides during mixing. During pyrolysis of the PMS-10 mass $\%$ $\mathrm{TiCl}_{4}$ precursor, a silicon rich $\mathrm{Si}-\mathrm{Ti}-\mathrm{C}$ state was obtained below $973 \mathrm{~K}$, which simultaneously formed crystalline $\mathrm{Si}, \mathrm{TiSi}_{2}$, and $\mathrm{SiC}$ phases at relatively low temperatures below $1273 \mathrm{~K}$. During pyrolysis of the PMS-MoCl $\mathrm{P}_{5}$ precursors, however, formation of crystalline $\mathrm{Si}$ and $\mathrm{SiC}$ phases were not accelerated, while the crystalline $\beta$ $\mathrm{MoSi}_{2}$ or $\alpha-\mathrm{MoSi}_{2}$ phase was formed rapidly.

[Received June 19, 2005; Accepted March 16, 2006]
\end{abstract}

Key-words : Silicon carbide, Metal silicides, Precursor method, Polymethylsilane, Cross-link

\section{Introduction}

The polymer precursor method provides useful routes for synthesizing non-oxide ceramic materials with unique forms that are normally difficult to obtain using the conventional powder processing method. The microstructure of the obtained non-oxide ceramics is also unique, and varies from the amorphous to the nano-crystalline state.

Synthesis of continuous silicon carbide fiber from polycarbosilane is the most typical case that has been investigated in detail. $^{1), 2)}$ After the invention of SiC fibers, recent developments in organometallic chemistry led to the synthesis of novel precursors. ${ }^{3)-5)}$ There is now a large number of reports on various methods of precursor synthesis and utilization. ${ }^{6)-10)}$

Synthesis of a relatively new homo-polymer or co-polymer, however, is costly and takes time. For a wide range of applications, synthesis of the promising precursors using a combination of limited chemical compounds would be convenient and economical. Polymer blends of different precursors, the addition of alkoxides, or cross-linking agents, and the selection of metal fillers will be the key technologies to be addressed for the synthesis of new hybrid precursors. ${ }^{11)-17)}$

Polymethylsilane has been employed as a precursor for silicon carbide because of its starting stoichiometeric composition $\left(-\left(\mathrm{SiH}\left(\mathrm{CH}_{3}\right)\right)_{n}-\right)$. It was, however, observed that the resulting pyrolysis products always contained excess silicon due to the cleavage of $\mathrm{Si}-\mathrm{CH}_{3}$ bonds and $\mathrm{CH}_{4}$ evolution. ${ }^{13), 14), 18), 19)}$

The formation of new composites with various phases have been reported by Seyferth et. al., made possible by the pyrolysis of PMS including metal fillers. ${ }^{13), 20)}$ The process they employed was based on a solid state reaction between inorganic $\mathrm{Si}-\mathrm{C}$ amorphous and metal particles through direct ceramicmetal contacts, which could be chemically activated. Kim et al. have investigated the combination of polymethylsilane and $\mathrm{MoCl}_{5}$ in place of Mo fillers and have reported $\beta$-MoSi ${ }_{2}$ formation at $1273 \mathrm{~K}$, which suggests a special chemical interaction between PMS and $\mathrm{MoCl}_{5}{ }^{21)}$

In this article, a method for PMS modification using metal chlorides $\left(\mathrm{TiCl}_{4}\right.$ or $\left.\mathrm{MoCl}_{5}\right)$ has been described followed by the ceramization process. Formation of titanium silicide or molybdenum silicide phase was focused during the pyrolysis process. These silicide phases intrinsically possess high temperature resistance in an oxidative atmosphere because of the formation of silica based oxide layers identical to $\mathrm{SiC}$ surface. ${ }^{22)-27)}$ In particular, $\mathrm{SiC}-\mathrm{MoSi}_{2}$ ceramics have been actively investigated in connection with heating element applications.

The sectile property of the resulting materials is also promising, because the complex interface between $\mathrm{SiC}_{-} \mathrm{TiSi}_{2}$ or $\mathrm{SiC}-\mathrm{MoSi}_{2}$, formed by the precursor method, may prevent sudden crack propagation during machining and manufacturing. The expected strong interaction between $\mathrm{Si}-\mathrm{H}$ and metal chlorides during the mixing and the successive heat treatment probably yields a more complex interface than the PMS-metal filler systems examined in the previous works. The potential use of such systems in developing "nano materials" by adjusting the whole cross-linking reaction is attracting attention. 


\section{Experimental}

2.1 Preparation of starting materials

The synthesis process for the starting polymethylsilane (PMS) by a condensation reaction of methyldichlorosilane (Shin-Etsu Chemical Co., Ltd.) has been described elsewhere. ${ }^{14)}{ }^{28)}$ The PMS obtained was a pale yellow viscous liquid $\left(M_{\mathrm{w}}=1780, M_{\mathrm{w}} / M_{\mathrm{n}}=2.0\right)$, which has been reported to possess a partially cross-linked structure, $\left[\left(\mathrm{CH}_{3} \mathrm{SiH}\right)_{0.60^{-}}\right.$ $\left.\left(\mathrm{CH}_{3} \mathrm{Si}\right)_{0.40}\right]_{n}$. $\mathrm{TiCl}_{4}$ and $\mathrm{MoCl}_{5}$ were procured from Wako Pure Chemical Industries Ltd. and were used without further purification.

2.2 Synthesis and pyrolysis of the polymethylsilanetitanium chloride $\left(\mathrm{TiCl}_{4}\right)$ precursors

Mixing of $\mathrm{TiCl}_{4}$ with PMS was performed in a glove box under an $\mathrm{N}_{2}$ flow to avoid moisture contamination. A $10 \%$ PMS solution (by mass) in toluene was prepared for mixing with the $\mathrm{TiCl}_{4}$. The mixing mass ratios of the PMS-TiCl ${ }_{4}$ were 100-0, 90-10, 70-30, 60-40, 50-50, 40-60, and 25-75, which correspond to the $\mathrm{Ti} / \mathrm{Si}$ molar ratios of $0,0.03,0.10,0.16$, 0.35 , and 0.70 . The prepared $\mathrm{PMS}-\mathrm{TiCl}_{4}$ solution was placed at the bottom of a glass tube $(500 \mathrm{~mm}$ in length, $30 \mathrm{~mm}$ in diameter) equipped with a vacuum pump. After removing solvent by evaporation, the $\mathrm{PMS}-\mathrm{TiCl}_{4}$ mixture was heated at $723 \mathrm{~K}$ for $1 \mathrm{~h}$ under an Ar flow (heating rate up to $723 \mathrm{~K}$ was $5 \mathrm{~K} / \mathrm{min}$ ) to eliminate $\mathrm{HCl}$ from the precursor. The total mass of the PMS and $\mathrm{TiCl}_{4}$ settled in the glass tube was kept at ca. $3 \mathrm{~g} .1 \mathrm{~g}$ of the sample heat-treated at $723 \mathrm{~K}$ was placed in a quartz crucible, and was subsequently heat-treated at $1273 \mathrm{~K}$ by using a vertical furnace equipped with an automatic balance for in-situ thermoglavimetric analysis. A $1 \mathrm{~g}$ sample heat-treated at $1273 \mathrm{~K}$ in a graphite crucible was further heated at $1573 \mathrm{~K}$ for $1 \mathrm{~h}$ in a vertical furnace equipped with $\mathrm{MoSi}_{2}$ heaters.

The XRD patterns of the pyrolyzed samples were investigated (Model RINT 1100, Rigaku) using $\mathrm{Cu} \mathrm{K} \alpha$ radiation. Some of the pyrolysis products were mounted in epoxy resin in order to observe their polished cross-sections using an electron microprobe analyzer (EPMA JXA-870, JEOL).

2.3 Synthesis and pyrolysis of polymethylsilane-molybdenum chloride $\left(\mathrm{MoCl}_{5}\right)$ precursors

Mixing of $\mathrm{MoCl}_{5}$ with PMS, followed by heat treatment up to $1273 \mathrm{~K}$, was performed in a similar manner to that of the PMS-TiCl 4 mixture. The mixing mass ratios of $\mathrm{PMS}-\mathrm{MoCl}_{5}$ were $80-20,70-30,60-40,40-60$, and $30-70$, which correspond to the $\mathrm{Mo} / \mathrm{Si}$ molar ratios of $0,0.04,0.07,0.11,0.24$, and $0.38 .1 \mathrm{~g}$ of a sample in a graphite crucible was further heated to $1773 \mathrm{~K}$ for $1 \mathrm{~h}$ in a furnace equipped with $\mathrm{MoSi}_{2}$ heaters.

The XRD pattern measurements and elemental mappings on the pyrolysis products were also performed in a similar manner to those for the PMS- $\mathrm{TiCl}_{4}$ systems.

\section{Results and discussion}

3.1 Ceramization process of the $\mathrm{PMS}-\mathrm{TiCl}_{4}$ precursors After evaporation of toluene from the starting materials, a highly viscous and homogeneous mixture was obtained from $10 \% \mathrm{PMS}^{-\mathrm{TiCl}_{4}}$ precursor with an orange color. For a $\mathrm{TiCl}_{4}$ content of more than $10 \%$, the precursors were solidified during the solvent evaporation. After complete drying, a deep orange colored powder was obtained. Most of the mixtures and the original PMS were highly flammable in air. The PMS-TiCl ${ }_{4} 10 \%$ mixture was, however, relatively stable, and did not ignite under atmospheric conditions.

After heat treatment at $723 \mathrm{~K}$, the original PMS was transformed to a light orange solid, while the 10, 30, 40, 50\%

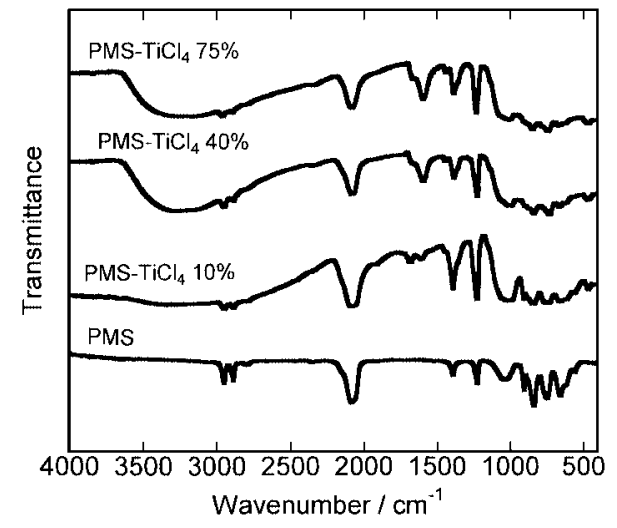

Fig. 1. IR spectra of the $\mathrm{PMS}-\mathrm{TiCl}_{4}$ precursors.

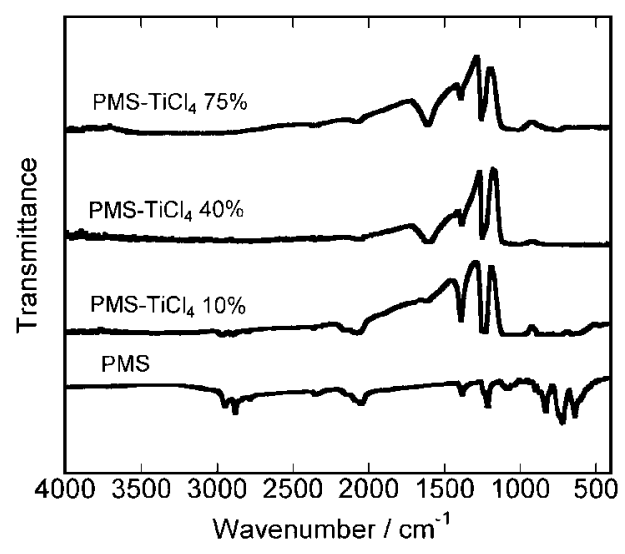

Fig. 2. IR spectra of the $\mathrm{PMS}-\mathrm{TiCl}_{4}$ precursors heated at $523 \mathrm{~K}$.

PMS- $\mathrm{TiCl}_{4}$ samples became black solids, whereas the 60 and $75 \% \mathrm{PMS}^{-\mathrm{TiCl}_{4}}$ samples showed a deep purple color. The 60

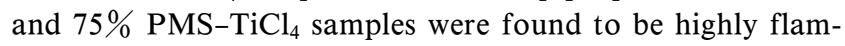
mable under atmospheric conditions, even after heat treatment at $723 \mathrm{~K}$.

Figure 1 shows IR spectra of the dried PMS-TiCl 4 samples. Broad absorption in the vicinity of $900-500 \mathrm{~cm}^{-1}$ may reveal the existence of an inorganic network, such as $\mathrm{Si}-\mathrm{Ti}-\mathrm{C}$. There is, however, no marked difference in the intensity of the $\mathrm{Si}-\mathrm{H}$ absorption $\left(2100 \mathrm{~cm}^{-1}\right)$. The Ti molar ratio is considered to be small to diminish the intensity of the $\mathrm{Si}-\mathrm{H}$ absorption. In the $40 \%$ and $50 \% \mathrm{PMS}^{-\mathrm{TiCl}_{4}}$ samples, broad absorption at 3300 and $1650 \mathrm{~cm}^{-1}$ were observed. Partial hydrolysis of residual $\mathrm{Ti}-\mathrm{Cl}$ by ambient moisture is suggested in these precursors for $\mathrm{OH}$ group introduction.

Figure 2 shows IR spectra of the $523 \mathrm{~K}$ heat-treated sam-

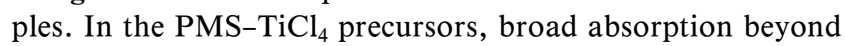
$1200 \mathrm{~cm}^{-1}$ overlaps the absorption bands of the organic groups. This may reveal the evolution of inorganic networks during the heat treatment. At high $\mathrm{TiCl}_{4}$ content, the intensity of $\mathrm{Si}-\mathrm{H}$ absorption showed a substantial decrease as compared with that of $\mathrm{Si}-\mathrm{CH}_{3}$ absorption.

Figure 3 shows the mass loss curves of the $723 \mathrm{~K}$ heattreated precursors (PMS, 10, 40, and 75\% $\mathrm{PMS}^{-\mathrm{TiCl}_{4}}$ ) up to $1273 \mathrm{~K}$ under an Ar atmosphere. It was observed that the original PMS precursor shows a mass loss of about $6 \%$ at $1273 \mathrm{~K}$. The residual mass at $1273 \mathrm{~K}$ decreases with $\mathrm{TiCl}_{4}$ content. Even the $10 \%$ and $40 \% \mathrm{PMS}^{-\mathrm{TiCl}_{4}}$ precursors exhibit notable mass loss beyond $1073 \mathrm{~K}$, possibly caused by $\mathrm{Ti}-\mathrm{Cl}$ 


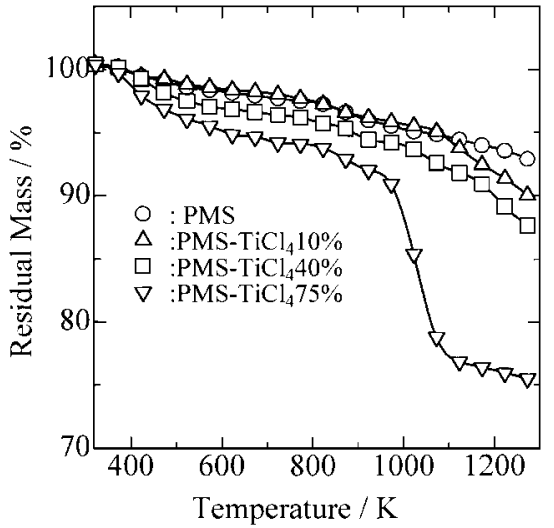

Fig. 3. Mass loss curves of the $\mathrm{PMS}^{-\mathrm{TiCl}_{4}}$ precursors in an $\mathrm{Ar}$ atmosphere.

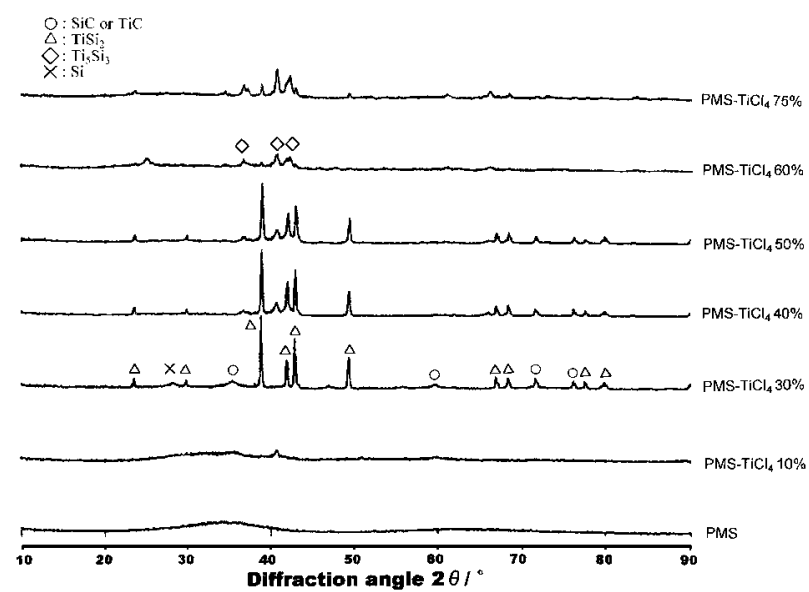

Fig. 4. XRD patterns of the PMS-TiCl 4 precursors pyrolyzed at $973 \mathrm{~K}$.

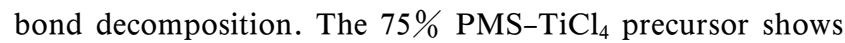
sharp mass loss at $850 \mathrm{~K}$. This possibly corresponds to the residual $\mathrm{TiCl}_{4}$ substance in the precursor. The small mass loss

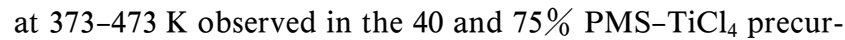
sors probably corresponds to the decomposition of $\mathrm{Ti}-\mathrm{OH}$ groups, which are formed by partial hydrolysis reaction of $\mathrm{Ti}-\mathrm{Cl}$ bonds during handling out of the glove box.

Figures 4 and 5 show the XRD patterns of the PMS- $\mathrm{TiCl}_{4}$ precursors pyrolyzed at 973 and $1273 \mathrm{~K}$, respectively. At $973 \mathrm{~K}$, the sharp lines of $\mathrm{TiSi}_{2}$ are clearly observed. The lines of $\mathrm{SiC}$ are, however, quite broad and show no indication of crystallite growth.

The PMS product (containing no $\mathrm{Ti}$ ) shows broad $\mathrm{SiC}$ lines at $1273 \mathrm{~K}$ (Fig. 5). Besides the $\mathrm{SiC}$ lines, the sharpened $\mathrm{TiSi}_{2}$ lines are observed in the $10-50 \% \mathrm{PMS}^{-} \mathrm{TiCl}_{4}$ products. The

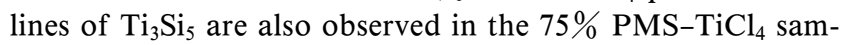
ple. The $10 \%$ and $30 \% \mathrm{PMS}^{-\mathrm{TiCl}_{4}}$ samples, however, show the sharp line of the metallic silicon phase at $1273 \mathrm{~K}$ in additional to the $\mathrm{TiSi}_{2}$ lines, unlike the XRD pattern of the PMS sample. It is not appropriate to assign the lines at 36,59 , and $70^{\circ}$ in the $10 \%$ and $30 \% \mathrm{PMS}^{-\mathrm{TiCl}_{4}}$ samples for $\mathrm{TiC}$, because the intensity of these lines is monotonously weakened as the $\mathrm{TiCl}_{4}$ content increases.

The chemical reaction between the $\mathrm{Si}-\mathrm{H}$ bonds and the $\mathrm{Ti}-\mathrm{Cl}$ bonds at rather low temperature may explain the $\mathrm{TiSi}_{2}-$

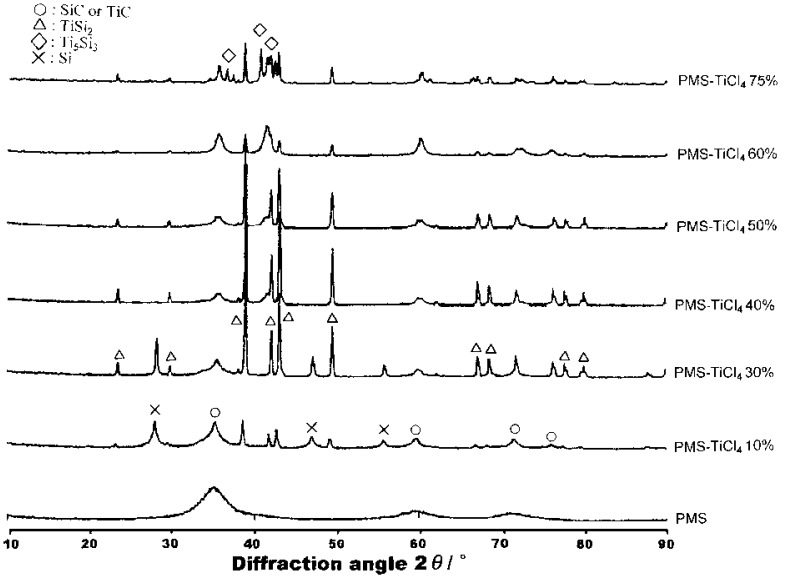

Fig. 5. XRD patterns of the $\mathrm{PMS}^{-} \mathrm{TiCl}_{4}$ precursors pyrolyzed at $1273 \mathrm{~K}$.

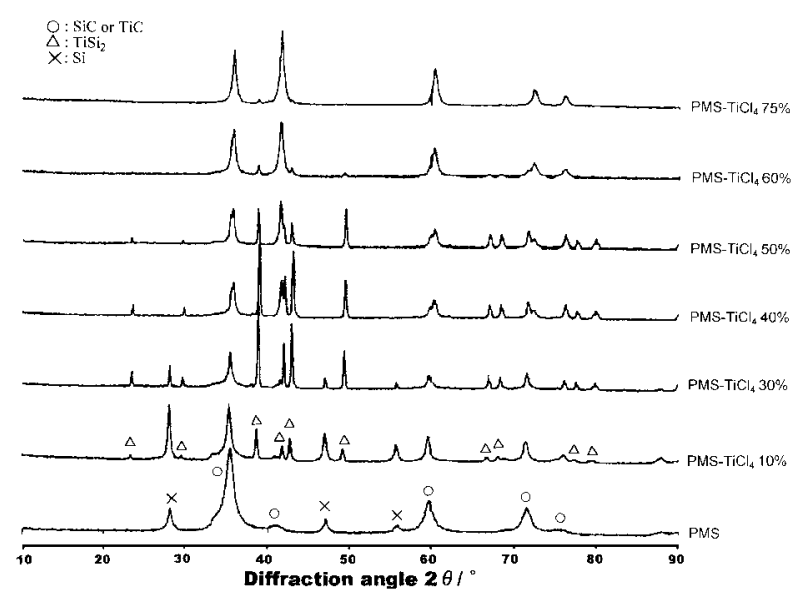

Fig. 6. XRD patterns of the $\mathrm{PMS}^{-} \mathrm{TiCl}_{4}$ precursors pyrolyzed at $1573 \mathrm{~K}$ (in a graphite crucible).

like domain formation. Strong Ti-Si bonds may accelerate cleavage of $\mathrm{Si}-\mathrm{CH}_{3}$ to eliminate methane from the whole system during pyrolysis; a possible reason for the metallic silicon phase formation at $1273 \mathrm{~K}$, and the absence of $\mathrm{Ti}_{3} \mathrm{SiC}_{2}$ phase. ${ }^{20)}$ It is known that the bond energy of the $\mathrm{Si}-\mathrm{Si}$ bond is lower than that of the $\mathrm{Si}-\mathrm{C}$ bond, and thus atomic migration will be accelerated in a silicon rich network that pushes forward segregation and crystallization of $\mathrm{TiSi}_{2}, \mathrm{SiC}$, and metallic silicon.

Figure 6 shows the XRD patterns of the $\mathrm{PMS}^{-\mathrm{TiCl}_{4}}$ products pyrolyzed at $1573 \mathrm{~K}$ in a graphite crucible. After pyrolysis, lines of metallic silicon are observed in PMS, 10 and $30 \% \mathrm{PMS}^{-\mathrm{TiCl}_{4}}$ samples in spite of the carbon rich atmosphere in the graphite crucible. In these XRD patterns, sharp $\mathrm{SiC}$ and $\mathrm{TiSi}_{2}$ lines are also observed. In the 40 and $50 \%$ $\mathrm{PMS}^{-\mathrm{TiCl}_{4}}$ samples, the $\mathrm{SiC}$ lines are split. This is due to $\mathrm{TiC}$ formation with the consumption of $\mathrm{TiSi}_{2}$.

Most of the PMS- $\mathrm{TiCl}_{4}$ precursors, except the 10\% PMS$\mathrm{TiCl}_{4}$ sample, show a powder-like appearance after solvent removal. Even during pyrolysis at high temperature, there was no indication of fusing. Thus, the $10 \% \mathrm{PMS}^{-\mathrm{TiCl}_{4}}$ precursor is most promising for a wide range of applications from the viewpoint of its processability. The low carbon content expected from $\mathrm{TiSi}_{2}$ and metallic silicon phase formation at low tem- 

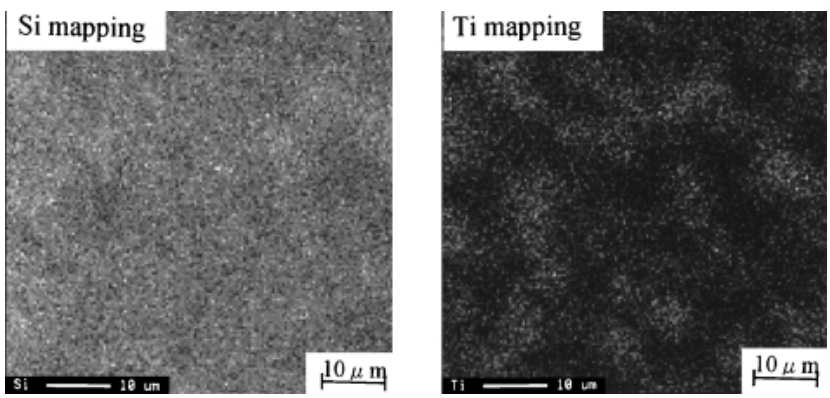

Fig. 7. $\mathrm{Si}$ and $\mathrm{Ti}$ mappings on the polished cross-section of the PMS-TiCl 4 10\% product at $1273 \mathrm{~K}$.

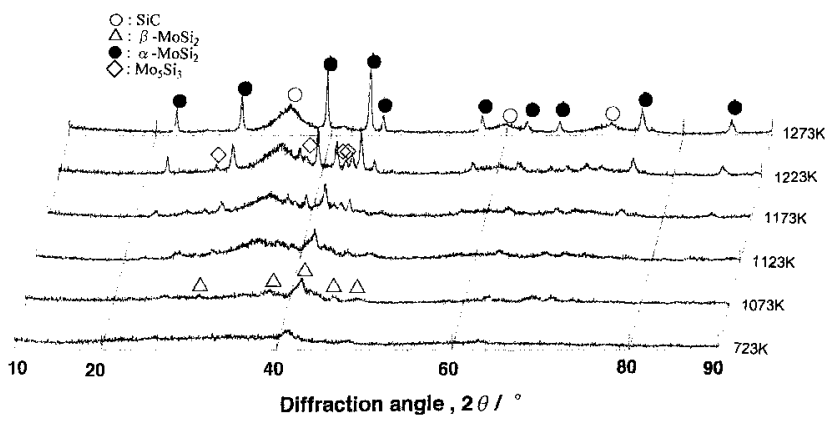

Fig. 8. XRD patterns of the PMS- $\mathrm{MoCl}_{5} 60 \%$ precursor pyrolyzed at various temperatures.

perature is also unique. On the other hand, the large amount of the $\mathrm{TiCl}_{4}$ addition probably introduces a large number of cross-linking points in the starting PMS precursor to thwart its processable nature.

In order to investigate the homogeneity of the PMS- $\mathrm{TiCl}_{4}$ $10 \%$ sample, a piece of the pyrolysis product was polished down to obtain element ( $\mathrm{Si}$ and $\mathrm{Ti}$ ) mappings of the cross-section (Fig. 7). It was observed that the distribution of silicon and titanium was not completely homogeneous. An undulating texture of $10-20 \mu \mathrm{m}$ was observed on the Si and Ti mappings. These patterns may correspond to the phase separation patterns in the starting polymers. PMS densely cross-linked by $\mathrm{TiCl}_{4}$ is possibly segregated from relatively low molecular weight PMS, which is not sufficiently cross-linked with $\mathrm{TiCl}_{4}$. The segregation process in such a system, however, does not proceed completely to form independent domains because the cross-linking points intrinsically retard any kind of diffusion process.

3.2 Ceramization process of the PMS- $\mathrm{MoCl}_{5}$ precursors After evaporation of toluene from the starting solutions, PMS- $\mathrm{MoCl}_{5}$ mixtures were obtained in the form of a black liquid. After heat treatment at $723 \mathrm{~K}$, these black liquids were converted to black solids.

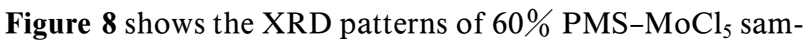
ples heat treated at various temperatures beyond $723 \mathrm{~K}$. In the low temperature region of $1073 \mathrm{~K}$, traces of $\beta$ - $\mathrm{MoSi}_{2}$ lines have already been observed. From $1173 \mathrm{~K}$ to $1273 \mathrm{~K}$, these $\beta$ - $\mathrm{MoSi}_{2}$ lines disappear with the appearance of $\alpha-\mathrm{MoSi}_{2}$ lines. In the same temperature region, broad $\mathrm{SiC}$ lines are also observed. The metallic silicon phase is absent up to $1273 \mathrm{~K}$.

Figure 9 shows the XRD patterns of the pyrolysis products of PMS- $\mathrm{MoCl}_{5}$ precursors at $1273 \mathrm{~K}$ with the various $\mathrm{MoCl}_{5}$ contents. At a low $\mathrm{MoCl}_{5}$ content of 20 mass $\%$, lines of $\alpha$ -

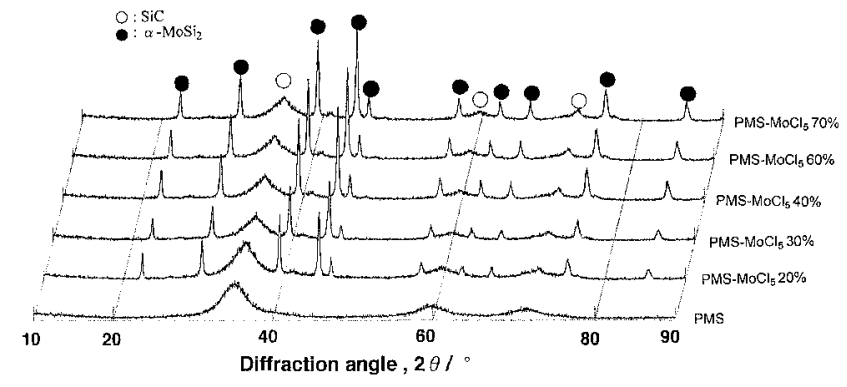

Fig. 9. XRD patterns of the PMS- $\mathrm{MoCl}_{5}$ precursors pyrolyzed at $1273 \mathrm{~K}$.
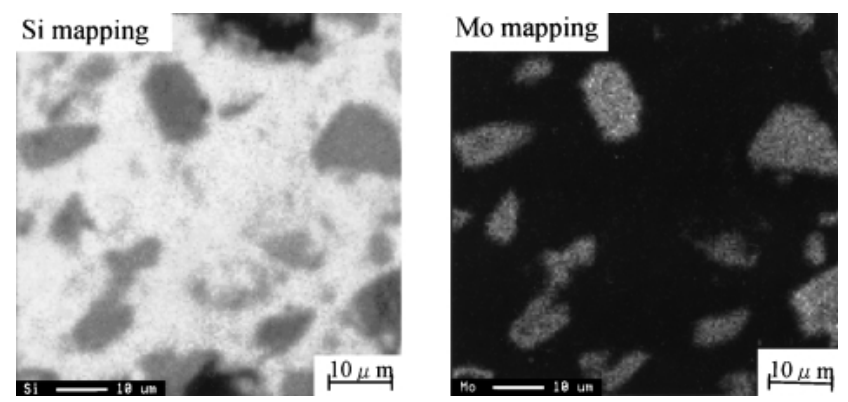

Fig. 10. Si and Mo mappings of the polished cross-section of the PMS- $\mathrm{MoCl}_{5} 30 \%$ product at $1273 \mathrm{~K}$.

$\mathrm{MoSi}_{2}$ phase are observed. As the $\mathrm{MoCl}_{5}$ content in the starting mixture increases, the line intensity of the $\alpha-\mathrm{MoSi}_{2}$ phase shows a small increase.

After heat treatment at $1773 \mathrm{~K}$ in a graphite crucible, the $20 \% \mathrm{PMS}^{-\mathrm{MoCl}_{5}}$ showed the line assigned to metallic silicon $\left(28^{\circ}\right)$. Its intensity was, however, quite low, which was different from the cases of the PMS-TiCl 4 precursors. As the $\mathrm{MoCl}_{5}$ content in the starting mixture increased, the lines assigned to $\alpha-\mathrm{MoSi}_{2}$ increased with the decrease of the $\beta$-SiC lines. In spite of the carbon rich atmosphere during pyrolysis, $\mathrm{Mo}_{2} \mathrm{C}$ phase was not formed. The $\alpha-\mathrm{MoSi}_{2}$ phase was sufficiently stable and the system did not contain metallic Mo.

Figure 10 (a) shows elemental mappings of the cross-section of the pyrolysis product at $1273 \mathrm{~K}$ derived from the PMS-30\% $\mathrm{MoCl}_{5}$ precursor. Mo rich domains with irregular sizes were dispersed in the silicon rich domains. Elemental analysis of the dispersed domains generally indicated a composition of $\mathrm{SiC}$ and $\mathrm{MoSi}_{2}$. On the other hand, the composition of the matrix area was consistent with silicon rich $\mathrm{SiC}$. The obtained results indicate that the Mo rich domains always contain a considerable amount of $\mathrm{SiC}$, while the matrix area contained almost no Mo.

Such a microstructure, however, was influenced by the solvent and additives used for the precursor preparation. As an example, the microstructure of the pyrolysis product of PMS-20\% $\mathrm{MoCl}_{5}$ precursor prepared with a large amount of THF (tetrahydrofuran) ${ }^{21), 29)}$ is shown in Fig. 11. The Mo rich domain shows a spherical or droplet shape, which consists of small Mo rich particles. The Mo rich particles and the Si rich matrix form a complex interface in the observed droplets. In Fig. 11, we can observe the removal of one small Mo rich particle from the droplet isolated in the matrix.

XRD measurements on the PMS- $\mathrm{MoCl}_{5}$ pyrolysis products indicated the existence of a high temperature, hexagonal $\beta$ - 

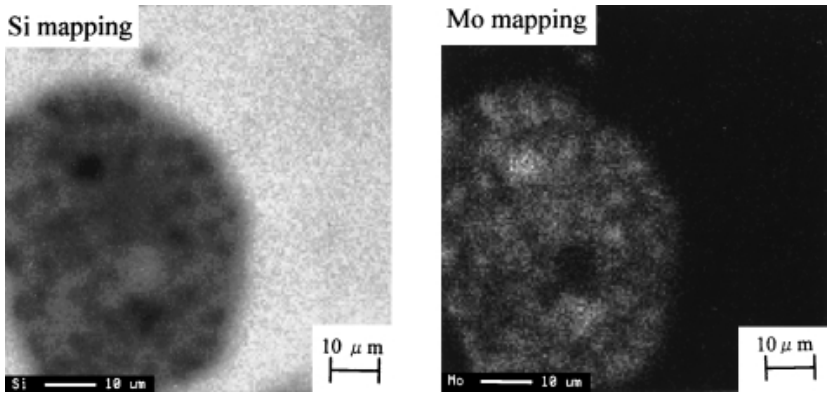

Fig. 11. Si and Mo mappings of the polished cross-section of the PMS- $\mathrm{MoCl}_{5} 30 \%$ product at $1273 \mathrm{~K}$. A 10 -times mass of tetrahydrofuran is used for the $\mathrm{MoCl}_{5}$ dissolution in the starting mixture.

$\mathrm{MoSi}_{2}$ phase formation in quite a low temperature region. Such $\beta-\mathrm{MoSi}_{2}$ phase formation at low temperature has been reported in cases of mechanical millings of $\mathrm{Mo}$ and $\mathrm{Si}$ powders. ${ }^{30)}$ In our case, it is probable that the strong chemical interaction between PMS and $\mathrm{MoCl}_{5}$ forms $\mathrm{Si}-\mathrm{Mo}$ bonds during mixing, which are then converted to a molybdenum silicide-like structure during pyrolysis.

The observed microstructure at $1273 \mathrm{~K}$ is quite different from the microstructure of the $\mathrm{PMS}-\mathrm{TiCl}_{4}$ products. This difference is possibly caused by the valance of the $\mathrm{MoCl}_{5}$, the solubility of the used solvent, and the interaction between PMS and $\mathrm{MoCl}_{5}$. This issue, however, requires further investigation. The polarity of the used solvent and the types of additives for PMS cross-links will be major factors.

\section{Summary}

$\mathrm{TiCl}_{4}$ added in PMS possibly reacts with almost all the PMS networks to yield $\mathrm{Si}-\mathrm{Ti}$ bonds. The $\mathrm{TiSi}_{2}$ phase is formed at $973 \mathrm{~K}$. $\mathrm{TiSi}_{2}, \mathrm{SiC}$ and $\mathrm{Si}$ phase crystallization at $1273 \mathrm{~K}$ is accelerated with the $\mathrm{TiCl}_{4}$ addition. At a high $\mathrm{TiCl}_{4}$ content beyond $50 \%, \mathrm{Ti}_{3} \mathrm{Si}_{5}$ phase is formed, which is easily converted to $\mathrm{TiC}$ at $1573 \mathrm{~K}$ (in a carbon rich atmosphere). From the $\mathrm{TiCl}_{4}$ content of $30 \%$, the powdery precursor is obtained after solvent removal. Therefore, $0-10$ mass $\%$ of $\mathrm{TiCl}_{4}$ is considered to be appropriate to modify PMS from the viewpoint of processability.

$\mathrm{MoCl}_{5}$ added in PMS also reacts with PMS to form Si-Mo bonds, which are converted to $\mathrm{SiC}-\mathrm{MoSi}_{2}$ domains during pyrolysis. Formation of $\beta-\mathrm{MoSi}_{2}$ phase at $1073 \mathrm{~K}$, which usually appears as a high temperature stable phase, also suggests the strong chemical interaction between Si and Mo. The conversion process of $\beta-\mathrm{MoSi}_{2}$ to $\alpha-\mathrm{MoSi}_{2}$ crystalline phase proceeds at $1273 \mathrm{~K}$. The microstructure of the obtained ceramics, however, depends upon the types of solvent used for the precursor mixing.

Acknowledgements This work was partly supported by the National Research Laboratory (Grant No. M 1040000006104J0000-06110), sponsored by the Korean Ministry of Science and Technology. We would also like to thank Dr. Amit Asthana of the Chungnam National University for his comments on the written manuscript.

\section{References}

1) Yajima, S., Hayashi, J. and Omori, M., Chem. Lett., pp. 931-934 (1975)

2) Okamura, K., Composites, Vol. 18, pp. 107-120 (1987).

3) West, R., David, L. D., Djurovich, P. I. and Yu, H., Am. Ceram. Soc. Bull., Vol. 62, pp. 899-903 (1983).

4) Schilling, C. L., Jr., Wesson, J. P. and Williams, T. C., Am. Ceram. Soc. Bull., Vol. 62, pp. 912-915 (1983).

5) Baney, R. H., Gaul, J. H., Jr. and Hilty, T. K., Organometallics, Vol. 2, pp. 859-864 (1983).

6) Cooke, T. F., J. Am. Ceram. Soc., Vol. 74, pp. 2959-2978 (1991).

7) Laine, R. M. and Babonneau, F., Chem. Mater., Vol. 5, pp. 260-279 (1993).

8) Birot, M., Pillot, J.-P. and Dunogues, J., Chem. Rev., Vol. 95, pp. 1443-1477 (1995).

9) Bill, J. and Aldinger, F., Adv. Mater., Vol. 7, pp. 775-787 (1995).

10) Baldus, H.-P. and Jansen, M., Angew. Chem. Int. Ed. Engl., Vol. 36, pp. 328-343 (1997).

11) Yajima, S., Iwai, T., Yamamura, T., Okamura, K. and Hasegawa, Y., J. Mater. Sci., Vol. 16, pp. 1349-1355 (1981).

12) Yamamura, T., Ishikawa, T., Shibuya, M., Hisayuki, T. and Okamura, K., J. Mater. Sci., Vol. 23, pp. 2589-2594 (1988).

13) Seyferth, D., Bryson, N., Workman, D. P. and Sobon, C. A., J. Am. Ceram. Soc., Vol. 74, pp. 2687-2689 (1991).

14) Seyferth, D., Wood, T. G., Tracy, H. J. and Robison, J. L., J. Am. Ceram. Soc., Vol. 75, pp. 1300-1302 (1992).

15) Toreki, W., Batich, C. D., Sacks, M. D., Saleem, M., Choi, G. J. and Morrone, A. A., Composite Sci. Technol., Vol. 51, pp. 145-159 (1994)

16) Greil, P., J. Am. Ceram. Soc., Vol. 78, pp. 835-848 (1995).

17) Moraes, K., Vosburg, J., Wark, D., Interrante, L. V., Puerta, A. R., Sneddon, L. G. and Narisawa, M., Chem. Mater., Vol. 16, pp. 125-132 (2004).

18) Zhang, Z., Babonneau, F., Laine, R., Mu, Y., Harrod, J. F. and Rahn, J. A., J. Am. Ceram. Soc., Vol. 74, pp. 670-673 (1991).

19) Kobayashi, T., Sakakura, T., Hayashi, T., Yumura, M. and Tanaka, M., Chem. Lett., pp. 1157-1160 (1992).

20) Seyferth, D. and Czubarow, P., Chem. Mater., Vol. 6, pp. 10-12 (1994).

21) Kim, D.-P., Mater. Res. Bull., Vol. 36, pp. 2497-2505 (2001).

22) Tong, X., Okano, T., Iseki, T. and Yano, T., J. Mater. Sci., Vol. 39, pp. 3087-3090 (1995).

23) Li, J., Jiang, D. and Tan, S., J. Eur. Ceram. Soc., Vol. 20, pp. 227-233 (2000).

24) Du, Y. and Schuster, J. C., Seifert, H. J. and Aldinger, F., J. Am. Ceram. Soc., Vol. 83, pp. 197-203 (2000).

25) Petrovic, J. J. and Honnel, R. E., Ceram. Eng. Sci. Proc., Vol. 11, pp. 734-744 (1990).

26) Costa e Silva, A. and Kaufman, M. J., Metall. Mater. Trans. A, Vol. 25A, pp. 5-15 (1994).

27) Chen, H., Suzuki, M., Sodeoka, S., Inoue, T. and Ueno, K., J. Mater. Sci., Vol. 36, pp. 5773-5777 (2001).

28) Narisawa, M., Yoshida, T., Iseki, T., Katase, Y., Okamura, K., Oka, K. and Dohmaru, T., Chem. Mater., Vol. 12, pp. 2686-2692 (2000).

29) Wang, H., Li, X. D. and Kim, D. P., Appl. Organomet. Chem., Vol. 19, pp. 742-749 (2005).

30) Orru, R., Woolman, J. and Munir, Z. A., J. Mater. Res., Vol. 16, pp. 1439-1448 (2001). 